\title{
PENGARUH PENGORGANISASIAN MATERI FISIKA MENGGUNAKAN ANALISIS INTRUKSIONAL TERHADAP HASIL BELAJAR FISIKA SISWA
}

\author{
Oleh: I Made Astra *), Asep Saefuloh Alrasi ${ }^{* *}$
}

\section{Abstrak}

Penelitian ini bertujuan untuk mengetahui pengaruh pengorganisasian materi Fisika menggunakan analisis intruksional terhadap hasil belajar Fisika siswa. Metode yang digunakan dalam penelitian ini adalah quasi eksperimen, yaitu suatu metode penelitian untuk melihat suatu hasil, dalam hal ini hasil belajar Fisika. Berdasarkan analisis dan perhitungan yang dilakukan terhadap data yang diperoleh dari penelitian, maka dapat disimpulkan bahwa peng-organisasian materi menggunakan analisis instruksional yang diterapkan di kelas eksperimen berpengaruh signifikan terhadap peningkatan hasil belajar siswa. Hal ini sesuai dengan hasil uji hipotesis dimana $\mathrm{H}_{0}$ ditolak, sedangkan $\mathrm{H}_{1}$ diterima untuk hasil belajar siswa. Dengan diterimanya $\mathrm{H}_{1}$, maka dapat disimpulkan bahwa hasil belajar siswa yang diajar dengan pengorganisasian materi menggunakan analisis intruksional lebih tinggi dari pada hasil belajar siswa dengan pengorganisasian materi menggunakan silabus.Sehubungan dengan itu, maka pengorganisasian materi mengguna-kan analisis intruksional dapat digunakan sebagai salah satu cara untuk meningkatkan hasil belajar siswa. Karena dengan materi yang terorganisir dengan baik dan sistematis dapat memudahkan siswa memahami materi dan memotivasi siswa untuk terus belajar, sehingga akhirnya tujuan pembelajaran dapat tercapai.

Kata Kunci : Analisis Instruksional, quasi Eksperimen

\section{PENDAHULUAN}

\section{A. Latar Belakang Masalah}

Sekolah merupakan sutau lembaga yang menyelenggarakan pendidikan bagi masyarakat untuk dapat menuntut ilmu bagi masa depan mereka dan masa depan Bangsa. Sekolah juga merupakan tempat bagi para senior pendidikan untuk menurunkan pengetahuan dan pengalaman mereka kepada masyarakat yang terdaftar sebagai anggota di sekolah itu. Oleh karena itu, keberadaan sekolah di dunia pendidikan sangatlah penting dan utama. Dimana arti dari pendidikan itu sendiri merupakan interaksi manusiawi (Human Interaction) antara pendidik/guru dengan siswa yang dapat menunjang pengembangan manusia seutuhnya yang berorientasi pada nilai-nilai dan pelestarian serta pengembangan kebudayaan yang berhubungan dengan usaha-usaha pengembangan tersebut.

Menurut Drijiarkara SJ dalam Ari H. Gunawan (1986 :1), pendidikan adalah memanusiakan manusia muda, jadi pendidikan tersebut oleh manusia dewasa dengan upaya-upaya yang kuat serta strategi dan siasat yang tepat demi keberhasilan pendidikan. Hal yang sama di

\footnotetext{
*) Dr. I Made Astra, M.Si., adalah dosen Fisika pada Universitas Negeri Jakarta

*) Asep Saefuloh Alrasi, S.Pd., adalah Guru SMA di Purwakarta
} 
ungkapkan oleh Surakhmad (1984:74), "belajar dapat dipandang sebagai suatu proses yaitu pada saat guru melihat kejadian selama murid mengalami pengalaman edukatif untuk mencapai suatu tujuan".

Untuk mengukur keberhasilan siswa dalam suatu proses pembelajaran dapat ditentukan oleh beberapa faktor seperti, terjadinya perubahan tingkah laku menjadi positif setelah pembelajaran, mampu memahami dan menganalisis materi yang diajarkan. Selain itu, masih ada banyak hal yang lain seperti, apektif dan psikomotorik yang dapat dilihat dari keseharian kelakuan siswa saat proses pembelajaran berlangsung.

Keberhasilan suatu kegiatan pembelajaran juga tergantung pada interaksi komponen penyusunnya yang terdiri atas guru (sebagai pengelola kelas), siswa (sebagai pembelajar), dan materi subjek (sebagai rujukan). Masingmasing komponen akan saling berinteraksi berdasarkan hubungan ketergantungan yang saling menguntungkan dalam mengkonstruksi pengetahuan (Siregar, 1998 :1).

Sebagai guru atau pendidik dituntut untuk mempersiapkan suatu materi yang akan disampaikan dalam kegiatan balajar mengajar. Secara tradisional biasanya kita mengikuti isi suatu buku untuk menentukan materi pelajaran. Apa yang tercantum di dalam buku, itulah yang disampaikan kepada siswa.

Berbeda dengan cara yang tradisional tersebut, sekarang telah ada usaha-usaha yang dilakukan oleh para ahli riset untuk mendapatkan prosedur yang lebih efektif dan efisien dalam menentukan materi pelajaran, yang dengannya diharapkan siswa memperoleh penetahuan, keterampilan dan sikap yang diharapkan seperti telah dirumuskan di dalam tujuan intruksional. Cara baru yang dimaksud adalah dengan mengidetifikasi setepat-tepatnya tentang kemampuan apa yang dimiliki siswa setelah menyelesaikan suatu mata kuliah, unit atau topik pelajaran tertentu. Langkah selanjutnya adalah mengidentifikasi sub kemampuan yang harus dimiliki untuk mencapai tujuan intruksional tadi. Cara baru ini dikenal dengan nama analisis intruksional. Abd. Gafur (1984
$: 43-44)$

Dengan mengguakan analasis intruksional dapat dibuat suatu organisasi materi yang terstuktur dan sistematis sesuai dengan pedekatan prosedural dan hierarkhial, untuk memudahkan siswa mencapai tujuan pembelajaran.

Pengorganisasian materi tiap kompetensi dasar akan berbeda, sesuai dengan konsepkonsep yang terdapat dalam materi tersebut. Guru harus dapat membuat suatu tahapan yang sistematis untuk menggali pengetahuan awal dan membantu pengkonstruksian pengetahuan siswa dalam proses belajar mengajar. Dengan begitu, pengetahuan awal siswa dapat diketahui dan pengetahuan baru yang diberikan dapat dikonstruksi dan diimprovisasi dengan baik oleh siswa. Flander (1967) dalam Siregar (1998: 37) menyatakan bahwa perlu proses kognitif yang dihubungkan dengan materi subjek dan interaksi sosial dalam pembelajaran.

Ada beberapa masalah yang dihadapi oleh guru dalam menyajikan suatu materi tertentu kepada siswa pada saat pembelajaran. Devis, menyatakan bahwa masalah yang dihadapi oleh guru pada saat pembelajaran dapat dikelompokan menjadi isi dan urutan pengajaran, evaluasi, metode dan hambatanhambatan. Permasalahan pada isi dan urutan pengajaran diantaranya ketidak jelasan bahkan hilangnya konsep pelajaran dan ketidak logisan urutannya. Hal ini berdampak bagi siswa dalam memahami suatu materi pelajaran atau konsep-konsep yang dipelajari menjadi tidak bermakna (Rusyati, 1994 dalam Kosasih, 2005). Padahal menurut Anderson (1971) dalam Siregar (1998: 27) jika terdapat hubungan yang berurutan antara unit (tema) yang satu dengan unit lainnya akan terjadi peningkatan retensi siswa terhadap materi subjek.

\section{B. Identifikasi Masalah}

Dari latar belakang masalah diatas diidentifikasi beberapa masalah sebagai berikut:

1. Bagaimana cara mencapai kompetensi dasar pembelajaran fisika yang terdapat 
pada kurikulum tingkat satuan pendidikan?

2. Bagaimana cara membuat siswa mengerti suatu materi pelajaran dengan mudah?

3. Bagaimana cara membuat organisasi materi yang dapat memudahkan siswa memahami materi tersebut?

4. Bagaimana meningkatkan hasil belajar siswa?

5. Apakah dengan pengorganisasian materi menggunakan analisis intruksional dapat meningkatkan hasil belajar siswa?

6. Apakah dengan hanya mempelajari materi dari buku hasil belajar siswa baik?

7. Apakah ada pengaruh pengorganisasian materi menggunakan analisis intruksional terhadap hasil belajar siswa?

\section{Pembatasan Masalah}

Penelitian ini lebih memfokuskan perhatian pada pengaruh pengorganisasian materi menggunakan analisis intruksional terhadap hasil belajar Fisika siswa.

\section{Perumusan Masalah}

Berdasarkan latar belakang, identifikasi masalah dan pembatasan masalah yang telah disampaikan, maka perumusan masalah dalam penelitian ini adalah "apakah ada pengaruh pengorganisasian materi menggunakan analisis intruksional terhadap hasil belajar siswa?"

\section{E. Tujuan Penelitian}

Penelitian ini bertujuan untuk mengetahui pengaruh pengorganisasian materi menggunakan analisis intruksional terhadap hasil belajar siswa.

\section{F. Manfaat Penelitian}

Penelitian ini diharapkan dapat memberikan manfaat sebagai berikut :

\section{Bagi Siswa}

a. Dapat memahami materi pelajaran dengan baik dan mudah.

b. Dapat mengkontruksi pengetahuan yang baru diterimanya dengan pengetahuan yang telah dimiliki sebelumnya.

c. Mendapat hasil belajar yang lebih baik.

\section{Bagi Guru}

a. Memberikan gambaran kepada para guru mengenai peng-organisasian materi menggunakan analisis intruksional.

b. Guru bisa lebih mudah dalam menyampaikan materi karena telah terstruktur dengan baik.

c. Mengembangkan konsep dan mengaitkan satu konsep dengan konsep lain menjadi lebih baik sehigga tidak terdapat missing link dalam penyampaian suatu konsep yang masih dalam satu pokok bahasan.

\section{Pengembangan ilmu pendidikan}

a. Sebagai acuan dalam penyampaian materi pembelajaran

b. Dapat mempermudah pernyampaian dan penyerapan materi yang sulit dipahami oleh guru maupun siswa.

\section{LANDASAN TEORI}

\section{A. Pengorganisasian Materi}

Materi fisika cukup banyak dan beragam dan siswa harus mempelajari dan memahami materi tersebut dalam waktu yang sangat terbatas. Lembaga pendidikan di Indonesia menggunakan sistem kurikulum yang sudah ditetapkan berdasarkan standar kompetensi dan kompetensi dasar masing-masing materi. Dimana materi sudah dijelaskan secara garis besar. Setiap siswa wajib mempelajari semua materi yang sudah ditetapkan itu pada setiap bidang studi yang bersangkutan. Oleh sebab itu, guru sebagai pendidik dan fasilitator di kelas harus bisa membuat urutan materi yang teroganisasi dengan baik sehingga siswa dapat mudah menerimanya. Materi yang diberikan tidak boleh menyimpang dari apa yang sudah digariskan dalam kompetensi dasar materi. Carbum dalam Nomida (1994: 20) menjelaskan bahwa materi ajar yang diorganisasikan mempunyai tiga tujuan yaitu: mengkolidasikan atau memantapkan materi yang dipelajari, menyakini ketetapan materi dan menunjukan hubungan nyata antara konsep-konsep yang berkaitan dalam suatu topik dengan topik yang lain.

Reigeluth dan Merril (1994: 283) menguraikan variabel pembelajaran menajadi tiga kategori utama, yaitu stategi pengorganisasian materi, strategi penyampaian dan strategi pengelolaan. Strategi pengorganisasian materi adalah urutan materi yang akan disampaikan. 
Tarsono (1997: 7-8) menjabarkan ketiga kategori tersebut yaitu: strategi pengorganisasian, strategi penyampaian dan strategi pengelolaan.

\section{Strategi Pengorganisasian Materi}

Strategi pengorganisasian materi terbagi menjadi dua, yaitu strategi mikro yang berhubungan dengan tampilan tunggal, termasuk karakteristik-karakteristiknya, interaksi dan urutan-urutan yang diberikan kepada siswa. Strategi mikro disebut juga strategi tampilan, karena strategi ini berhubungan dengan desain tampilan tunggal. Sedangkan strategi makro berhubungan dengan pemilihan materi dan susunan topik masalah yang diberikan kepada siswa dalam satu semester atau satu tahun.

\section{Strategi Penyampaian}

Strategi penyampaian adalah keputusankeputusan yang mempengaruhi cara informasi disampaikan kepada siswa. Strategi penyampaian mempengaruhi pemilihan media pembelajaran yang dipakai untuk menjelaskan materi pelajaran.

\section{Strategi Pengelolaan}

Strategi pengelolaan adalah keputusankeputusan yang mempengaruhi cara bagimana siswa tertentu akan dibantu untuk berinteraksi dengan sumber belajar. Strategi pengelolaan melibatkan teknik, teknik motivasi, sekema individualisasi, penjadwalan, alokasi sumber dan implementasi aktivitas-aktivitas lain.

Pengorganisasian materi dalam penelitian ini tidak akan seperti yang dijabarkan dalam garis-garis besar program pembelajaran atau kurikulum, melainkan lebih mengarah pada bagaimana bentuk tampilan materi yang akan diberikan kepada siswa di kelas.

Tarsono (1997: 9) menyatakan bahwa pengorganisasian materi fisika merupakan suatu kegiatan untuk membuat tampilan materi pada papan tulis yang meliputi fakta, konsep, prosedur dan prinsip, inilah yang merupakan isi materi fisika. Isi materi ini yang akan disusun atau diorganisasikan tampilannya sehingga menghasilkan penampilan yang menarik, sistematis dan terarah untuk menuju pada tujuan yang hendak dipelajari.
Guru yang terbiasa menyusun materi ajar akan senantiasa mampu menyesuaikan kebutuhan siswanya, karena guru tersebut yang mengetahui kekurangan dan kelebihan siswanya.

Penjelasan diatas menunjukan betapa pentingnya pengorganisasian materi, sehingga dapat menunjang keberhasilan siswa dalam belajar.

\section{B. Analisis Intruksional}

Untuk membuat pengorganisasian materi menjadi suatu bahan ajar yang terstruktur dan tersusun dengan baik, ada banyak cara atau metode yang digunakan salah satunya yaitu dengan analisis intruksional.

Menurut Abd. Gafur (1984: 43 - 44) dalam bukunya tentang desain intruksional menyatakan bahwa, analisis intruksional ialah proses mengidentifikasi setepat-tepatnya tentang kemampuan apa yang dimiliki siswa setelah menyelesaikan suatu mata kuliah, unit atau topik pelajaran tertentu. Langkah selanjutnya adalah mengidentifikasi sub kemampuan yang harus dimiliki untuk mencapai tujuan intruksional.

Dick \& Carey dalam Abd. Gafur (1984: 44 45) menyatakan bahwa Analisis instruksional adalah suatu prosedur, yang apabila diterapkan pada suatu tujuan instruksional, akan menghasiikan suatu identifikasi kemampuan-kemampuan bawahan (sub ordinate skills) yang diperlu-kan bagi siswa untuk mencapai tujuan instruksional.

Sedangkan menurut Esseff, P.J, dalam Abd. Gafur (1984 : 45) menyatakan bahwa Analisis instruksional adalah suatu alat yang dipakai oleh para penyusu-n disain instruksional atau guru untuk membantu mereka di dalam mengidentifikasi setiap tugas pokok yang harus dikuasai atau dilaksanaan oleh siswa dan sub tugas atau tugas dasar yang membantu siswa dalam menyelesaikan tugas pokok.

Dari dua definisi tersebut dapat kita lihat "sub ordinate skills" itu sendiri sebenarnya bisa jadi tidaklah sangat penting sebagai hasil belajar, namun diperlukan, dalam arti harus dikuasai agar siswa dapat mempelajari ketrampilan (skill) yang lebih tinggi. Penguasaan "sub skill" 
tersebut akan memberikan transfer yang positif untuk mempelajari keterampilan yang lebih tinggi.

Berdasarkan definisi analisis intruksional diatas, dapat diambil arti yang sederhana bahwa analisis intruksional adalah suatu cara menyusun materi pembelajaran yang akan diberikan kepada siswa. Materi pembelajaran yang disusun memiliki urutan kompetensi kognitif yang bertingkat dan terstruktur, sehingga siswa mampu mencapai tujuan pembelajaran dengan lebih baik.

Dalam silabus pembelajaran, tujuan pembelajaran dijelaskan dengan indikator, kompetensi dasar kemudian standar kompetensi. Dalam indikator mengandung banyak sekali materi-materi pelajaran yang harus dikuasai siswa, namun terdapat kekurang strukturan dalam penyusunan materi. Hal ini dapat membuat siswa kurang terkonstruk pengetahuannya, karena bisa jadi materi dasar yang harusnya diberikan untuk menopang materi tersebut belum diajarkan. Dan terdapat juga ketidak bertingkatan kompetensi kognitif antara urutan materi dengan tujuan pembelajaran. Dalam silabus juga ada materi yang terlalu sempit untuk dipelajari, sedangkan materi tersebut dapat dimaksimalkan pentransferan pengetahuannya.

Oleh karena itu, jelas kiranya dengan menyu-sun analisis instruksional secara sistematis, maka dalam menentukan pelajaran (content lesson) yang akan dimasukkan di dalam suatu pengajaran, tidak mesti harus mengambil atau mengikuti suatu teks atau suatu artikel tertentu. Tapi yang penting terlebih dulu perlu diperhatikan ialah kemampuan yang harus diajarkan, agar siswa dapat mencapai tujuan pembelajaran dengan lebih baik.

Menurut Abd. Gafur (1984: 45 - 46) kegunaan analisis instruksional adalah sebagai berikut:

a. Membantu para guru/pendidik maupun penyusun disain instruksional untuk mengorganisir tugas-tugas pokok dalam hubungannya dengan subtugas yang harus dipelajari siswa. Pengorganisasiannya adalah sedemikian, sehingga merupakan urutan logis sesuai dengan keadaan sebenarnya manakala tugas tersebut dilaksanakan. Proses ini akan memberikan gambaran yang jelas bagi siswa mengenai yang diharapkan dapat dikerjakan setelah selesai mengikuti suatu pelajaran.

b. Membantu para guru di dalam menganalisis tingkah laku (behavior) berkenaan dengan masing-masing tugas pokok maupun subtugas. Dengan cara demikian, semua pengetahuan dan ketrampilan yang diperlukan untuk melaksanakan setiap tugas pokok dapat diidentifikasikan.

c. Membantu para penyusun disain instruksional dan para guru/pen-didik untuk memperkirakan waktu yang diperlukan untuk belajar, sehingga siswa dapat melaksanakan suatu tugas dengan baik.

\section{Metode \& Prosedur Analisis Instruksional} Istilah "metode" lebih menggambarkan pada teknik atau langkah-lang-kah, sedang istilah "prosedur" lebih ditekankan pada "pendekatan" di dalam melaksanakan analisis instruksional.

\section{a. Metode Analisis Instruksional.}

Metode dipergunakan untuk menjelaskan teknik serta langkah-langkah di dalam melaksanakan analisis instruksional. Menurut Mager dalam Abd. Gafur (1984: 46) langkah-langkah di dalam analisis istruksional dapat dibedakan dua macam:

1) Langkah pertama ialah menuliskan semua tugas-tugas yang harus dilaksanakan dalam menyelesaikan suatu pekerjaan.

2) Langkah kedua ialah menyusun, daftar tugas secara mendetail dan urut sesuai dengan urutan senyatanya manakala tugas itu dilaksanakan.

Apa yang dikemukakan oleh Mager tersebut menunjukkan, bahwa pada langkah pertama belum diperhatikan urutan bagaimana melak-sanakan tugastugas tersebut. Sedang pada langkah kedua, di samping memerinci sampai pada tugas yang sekecil-kecilnya agar tak ada yang terlewatkan, juga memperhatikan urutan bagaimana tugas 
tersebut dilaksanakan.

\section{b. Pendekatan Analisa Instruksional}

Dick \& Carey dalam Abdul Gafur (1984: 53) membedakan dua pendekatan pokok dalam analisis instruksional:

1) Pendekatan Prosedural

Pendekatan prosedural (procedural approach) dipakai bila tingkah laku yang diajarkan pada pokoknya merupakan serangkaian tindakan yang dilaksanakan secara berurutan (in sequence) untuk mencapai tujuan pembelajaran. Contoh sederhana ialah bila kita hendak mengajarkan siswa men-elepon. Beberapa hal dapat dicatat dari contoh tersebut: (a) Siswa harus melaksanakan kegiatan secara berurutan, (b) Masing-masing kegiatan bisa diajarkan secara terpisah (indepen-dent), dan (c) Output (hasil) dari setiap langkah merupakan input untuk langkah berikutnya.

Diagram umum pendekatan prosedural adalah sebagai berikut :

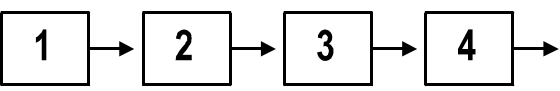

Gambar 1. Diagram Pendekatan Prosedural

2) Pendekatan secara hierarkhial.

Pendekatan secara hierarkhial dipakai untuk mengidentifikasi "subordinate skills" atau ketrampilanketrampilan yang mendahului atau membawahi (sub skills) yang harus dimiliki sebelum dapat men-capai tujuan instruksional.

Bagaimana cara mengidentifikasi sub ketrampilan yang harus dipelajari agar siswa dapat mencapai tujuan yang lebih tinggi? Untuk menjawab pertanyaan ini Gagne (1978: 28) memberikan pegarahan dengan cara mengajukan pertanyaan "Apakah yang harus sudah dikuasai oleh siswa, agar dengan pengajaran yang sedi-kit-dikitnya tugas tersebut akan dapat diketahui sub ketrampilan yang diperlukan sebelum siswa dapat menyelesaikan tugas terakhir?" Selanjutnya dapat pula dilanjutkan pertanyaan setelah sub ketram-pilan ditemukan "Apakah hal-hal yang harus sudah diketahui siswa, tanpa pengetahuan tersebut adalah tidak mungkin siswa dapat mempel-ajari tugas yang diberikan?"

Abdul Gafur (1984: 55) menggambarkan diagram analisis intruksional menurut pendekatan secara hierarkhial adalah sebagai berikut:

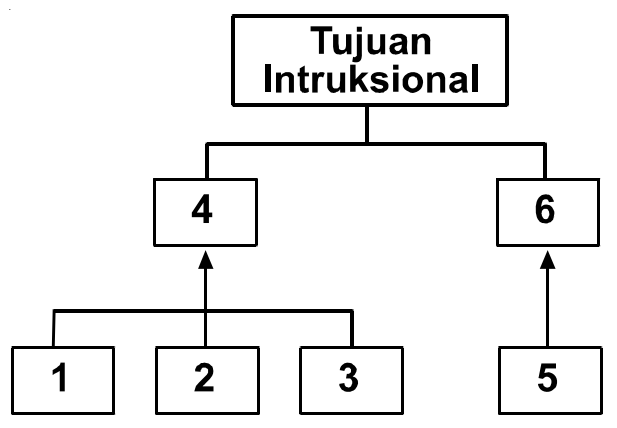

Gambar 2. Diagram Pendekatan Hierarkhial

\section{Fisika}

Fisika adalah ilmu pengetahuan yang berusaha menguraikan serta menjelaskan hukum-hukum dalam dan kejadian-kejadian alam dengan gambaran menurut pikiran manusia. Fisika merupakan salah satu cabang sains yang mempelajari tentang zat dan energi dalam segala bentuk manifestasinya (Elok Sudibyo, 2003: 5). Menurut Marcelo Alanso dan Edward J. Finn di definisikan sebagai ilmu yang tujuannya mempelajari komponen materi dan interaksi (Marcelo A, 1990: 2). Brochuos mendefinisikan Fisika sebagai pelajaran tetang gejala-gelaja alam, yang memungkinkan penelitian dengan percobaan, mengukur apa yang dihasilkan, dan mengkajikan secara matematis pertaturanperaturan umum (Druxes Herbert, 1989: 3).

Sebagai salah satu cabang sains, fisika merupakan ilmu pengetahuan yang paling mendasar, karena berkaitan dengan cara mencari tahu fenomena alam secara sistematik dan bukan hanya kumpulan faktafakta, konsep-konsep dan prinsip-prinsip saja tetapi juga merupakan proses penemuan. Horson (1984:1) berpendapat bahwa mata pelajaran Fisika banyak mengandug konsep- 
konsep, definisi dan rumus. Oleh karena itu pengetahuan dasar Aljabar dan Trigonometri diasumsikan berkaitan dengan aspek-aspek kualitatif mata pelajaran Fisika.

Dari uraian diatas, dalam penelitian ini yang dimaksud pembelajaran fisika adalah pembelajaran yang dimaksudkan untuk mendidik siswa yang berilmu dan berketerampilan yang unggul serta "open minded", memiliki etos kerja yang tinggi, melatih melakukan penelitian sesuai proses/ metode ilmiah dan belajar dengan mengaplikasikan pengetahauan terbaiknya dengan indikator siswa mempunyai sikap disiplin, jujur, dan bertanggung jawab. Disamping itu juga bersikap peka, tanggap dan berperan aktif dalam menggunakan fisika untuk memecahkan masalah di lingkungannya (Nursyamsudin, 2003 : 5).

\section{Hasil Belajar Fisika}

Hasil didefinisikan sebagai sesuatu yang telah dibuat (diadakan, dicapai dan sebagainya). Sedangkan belajar didefinisikan sebagai usaha menggunakan setiap sarana atau sumber di dalam maupun di luar pranata pendidikan, guna perkembangan dan pertumbuhan pribadi, (YB Sudarmanto: 1999). Psikologi Gestalt mengemukakan bahwa belajar adalah perubahan tingkah laku pada diri seseorang berkat pengalaman dan pelatihan.

Belajar merupakan suatu proses yang hasilnya ditandai dengan adanya perubahan pada diri seseorang. Perubahan tersebut berupa pengalaman, sikap, tingkah laku, daya penerimaan dan aspek lainnya.

(Nana Sudjana, 1986). Setiap kegiatan belajar menghasilkan suatu perubahan unsur yang dinamakan hasil belajar. Hasil belajar yang harus dicapai ada tiga macam yaitu: hasil belajar pengetahuan, konsep, fakta (kognitif) ; personal kepribadian, sikap (apektif); kelakuan, keterampilan dan penampilan (psikomotorik). (Roestiah: 1986).

Penilaian dapat digunakan sebagai alat untuk mengetahui keberhasilan proses dan hasil belajar siswa, dilihat dari segi pembelajaran bahwa proses adalah kegiatan yang dilakukan oleh siswa dalam mencapai tujuan pengajaran, sedangkan hasil belajar adalah berupa kemampuan-kemampuan yang dimiliki siswa setelah menerima pengalaman belajar.

Muhsin Lubis (1999: 6) menyatakan bahwa sistem pendidikan Nasional mengelompokan hasil belajar yang dirumuskan dalam tujuan pendidikan (tujuan kurikuler dan tujuan instruksional) adalah menggunakan domain atau ranah pendidikan dari Benyamin Bloom yang dibagi menjadi tiga ranah, yakni ranah kognitif, ranah afektif dan ranah psikomotorik. Dalam penelitian ini hasil belajar yang akan dijadikan sebagai alat penilaian keberhasilan siswa adalah ranah kognitif. Dimana menurut Muhsin Lubis (1999: 6) ranah kognitif adalah berkenaan dengan hasil belajar intelektual yang dibagi menjadi enam aspek : yaitu pengetahuan atau ingatan; pemahaman; aplikasi atau penerapan; analisa; sintesa dan evaluasi.

\section{METODOLOGI PENELITIAN}

\section{A. Waktu dan Tempat Penelitian}

Penelitian dilaksanakan pada semester 2 pada bulan Januari sampai dengan bulan Februari 2010 di SMP Taman Siswa Jakarta.

\section{B. Metode Penelitian}

Metode yang digunakan dalam penelitian ini adalah quasi eksperimen, yaitu suatu metode penelitian untuk melihat suatu hasil, dalam hal ini hasil belajar Fisika dengan desain sebagai berikut:

Tabel 1. Rancangan Desain Penelitian

\begin{tabular}{|l|c|c|c|}
\hline Kelompok & Pre test & Perlakuan & Post test \\
\hline Eksperimen & $\mathrm{Y}_{\mathrm{A}}$ & $\mathrm{X}_{\mathrm{A}}$ & $\mathrm{Y}_{\mathrm{B}}$ \\
\hline Kontrol & $\mathrm{Y}_{\mathrm{A}}$ & $\mathrm{X}_{\mathrm{B}}$ & $\mathrm{Y}_{\mathrm{B}}$ \\
\hline
\end{tabular}

Keterangan :

$\mathrm{X}_{\mathrm{A}}=$ Pembelajaran dengan pengorganisasi materi menggunakan analisis intruksional $\mathrm{X}_{\mathrm{B}}=\underset{\text { pembelajaran }}{\text { pengorganisasian }} \quad \begin{array}{r}\text { dengan } \\ \text { materi }\end{array}$ menggunakan silabus

$\mathrm{Y}_{\mathrm{A}}=$ Hasil belajar sebelum proses belajar mengajar

$\mathrm{Y}_{\mathrm{B}}=$ Hasil belajar sesudah proses belajar mengajar 
Tabel 2. Perbedaan kelas Eksperimen dan kelas Kontrol

\begin{tabular}{|c|c|c|}
\hline IIo & Kelas Eksperimen & Kelas Kontrol \\
\hline 1. & $\begin{array}{l}\text { Pengorganisasian materi } \\
\text { menggunakan analisis } \\
\text { intruksional }\end{array}$ & $\begin{array}{l}\text { Pengorganisasian materi } \\
\text { menggunakan silabus }\end{array}$ \\
\hline 2. & $\begin{array}{l}\text { 1. Energi } \\
\text { 2. Bentuk-bentuk energi } \\
\text { 3. Sumber Energi } \\
\text { 4. Energi potensial dan Energi } \\
\text { kinetik } \\
\text { 5. Hukum kekekalan energi } \\
\text { 6. Perubahan Energi } \\
\text { 7. Hukum kekekalan energi } \\
\text { mekanik } \\
\text { 8. Usaha dan hubungannya } \\
\text { dengan energi } \\
\text { 9. Daya dan hubungannya } \\
\text { dengan energy }\end{array}$ & $\begin{array}{l}\text { a. Bentuk - bentuk energi } \\
\text { dan contohnya } \\
\text { b. Energi dan Perubahan } \\
\text { energi } \\
\text { c. Energi potensial dan } \\
\text { Energi kinetik } \\
\text { d. Hukum kekekalan } \\
\text { energi } \\
\text { e. Hubungan usaha dan } \\
\text { energi } \\
\text { f. Daya }\end{array}$ \\
\hline 3. & $\begin{array}{l}\text { Materi lebih terorganisir dan } \\
\text { tidak ada materi yang hilang } \\
\text { dalam pembelajaran }\end{array}$ & $\begin{array}{l}\text { Materi kurang teorganisir } \\
\text { dan ada beberapa materi } \\
\text { yang hilang dalam } \\
\text { permbelajaran }\end{array}$ \\
\hline
\end{tabular}

Dalam penelitian perlakuan kepada kelas eksperimen dan kelas kontrol diusahakan sama untuk metode penyampaian, metode pembelajaran, alat dan sumber pembelajaran. Adapun yang dibedakan hanya pengorganisasian materinya saja, dimana untuk kelas eksperimen dengan pengorganisasian materi menggunakan analisis intruksional dan untuk kelas kontrol pengorganisasian materi menggunakan silabus.

\section{Teknik Pengambilan Sampel}

\section{Populasi}
a. Populasi Target : Seluruh siswa SMP Taman Siswa Jakarta yang terdaftar pada semester 2 tahun ajaran 2009 / 2010.
b. Populasi terjangkau Seluruh siswa kelas VIII SMP Taman Siswa Jakarta yang terdaftar pada semester 2 tahun ajaran 2009 / 2010.

\section{Sampel}

Sampel diambil dari populasi terjangkau sebanyak dua kelas secara acak, yaitu kelas VIII.1 sebagai kelas ekperimen dan kelas VIII.3 sebagai kelas kontrol.

\section{Teknik Pengumpulan Data}

Cara mendapatkan data mengenai hasil belajar siswa dari kelas sampel yang diteliti, diperoleh dari tes hasil belajar fisika yang berupa soal tes pilihan ganda.

1. Varibel: Variabel bebas pengorganisasian materi dan Varia-bel terikat hasil belajar siswa dalam pembelajaran fisika

2. Sumber data adalah sampel yang terdiri dari :

Kelas A : Kelas VIII.1 dengan jumlah siswa 30 orang

Kelas B : Kelas VIII.3 dengan jumlah siswa 30 orang

3. Rancangan Penelitian

Di dalam rancangan penelitian ini, perluakuan yang diberikan terhadap kelompok sampel yang diteliti adalah sebagai berikut :

a. Pembantukan kelas penelitian dengan cara penempatan acak (random assignment).

b. Pemberian tes awal (pre test) terhadap kelas sampel untuk mengetahui kemampuan siswa.

c. Kelas A belajar fisika dengan memakai pengorganisasian materi menggunakan analisis intruksional

d. Kelas B belajar fisika dengan pengorganisasian materi menggunakan silabus

e. Setelah seluruh pokok bahasan selesai, diadakan tes hasil belajar akhir (post test) terhadap dua kelas penelitian.

f. Hasil tes diuji dengan menggunakan uji-t (sampel bebas) untuk mencari perbedaan skor rata-rata antara kelas A dan kelas $B$. Kelas manakah yang mempunyai skor rata-rata lebih tinggi.

\section{E. Instrumen Penelitian}

Instrumen penelitian adalah alat untuk mengumpulkan informasi atau melakukan pengukuran (Suharsimi A, 1995: 100). 
Instrumen yang digunakan adalah jenis pilihan ganda berupa 15 butir soal dengan 4 option. Sebelum instrumen diberikan kepada sampel, tes tersebut diuji cobakan terlebih dahulu pada kelas yang telah mempelajari materi tersebut yaitu kelas IX, dengan tujuan apakah tes tersebut memenuhi persyaratan dari sebuah tes. Analisis yang dilakukan adalah analisis validitas, analisis butir soal dan analisis reliabilitas.

\section{Analisis Validitas}

Validitas adalah suatu alat ukur yang menunjukan tingkat-tingkat kevalidan atau kesahihan suatu instrument. Suatu instrument yang valid atau sahih mempunyai validitas tinggi. Untuk menganalisis validitas tiap butir soal digunakan rumus korelasi point biserial, yaitu :

$$
r_{p b i s}=\frac{M_{P}-M_{t}}{S_{t}} \sqrt{\frac{p}{q}}
$$

Keterangan :

$r_{\text {pbis }}=$ Koefisien korelasi point biserial

$M_{p}=$ Mean dari subyek-subyek yang menjawab benar item yang dicari kerelasinya dengan tes

$M_{t}=$ Mean skor total (rata-rata skor dari seluruh pengikut tes)

$\mathrm{S}_{\mathrm{t}}=$ standar deviasi skor total

$\mathrm{p}=$ Proporsi subyek yang menjawab benar

$q$ = Proporsi subyek yang menjawab salah

Setelah diperoleh koefisien korelasi point biserial $\left(r_{p b i s}\right)$ dari data yang diambil, kemudian dibandingkan dengan $r_{\text {tabel }}$ produk moment. Untuk $\alpha=0.05$ dan derajat kebebasan $(\mathrm{dk}=\mathrm{n}-2)$, maka untuk $r_{\text {hitung }}$ lebih besar dari $r_{\text {tabel }}$ berarti valid dan untuk $r_{\text {hitung }}$ lebih kecil dari $r_{\text {tabel }}$ berarti tidak valid. (Subana, dkk, 2000 : 159)

\section{Analisis butir soal}

\section{a. Analisis tingkat kesukaran}

Analisis tingkat kesukaran menyatakan tingkatan soal yang digunakan memiliki kategori mudah, sedang atau sukar. Untuk melakukan analisis tingkat kesukaran soal digunakan rumus:

$$
I=\frac{B}{N}
$$

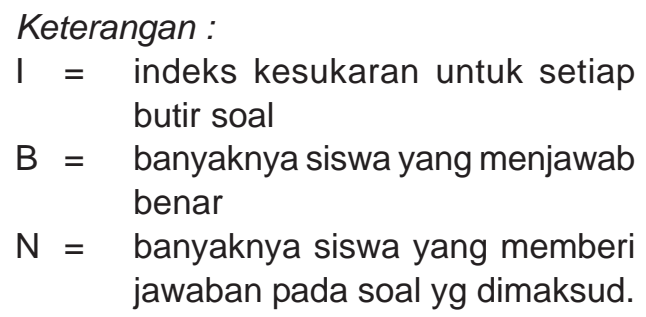

Kriteria yang digunakan yaitu :

$0-0,30=$ soal kategori sukar,

$0,31-0,70=$ soal kategori sedang

$0,71-0,90=$ soal kategori mudah.

(Muhsin L, 1999 : 34 - 35)

\section{b. Analisis daya pembeda}

Daya pembeda butir-butir soal dianalisis dengan tujuan untuk mengetahui kesanggupan soal dalam membedakan siswa yang tergolong mampu dengan siswa yang tergolong kurang. Rumus untuk menentukan daya pembeda soal adalah:

$$
D=\frac{B_{A}}{J_{A}}-\frac{B_{B}}{J_{B}}=P_{A}-P_{B}
$$

Keterangan :

$\mathrm{D}=$ daya pembeda

$\mathrm{J}_{\mathrm{A}}=$ banyaknya peserta kelompok atas

$\mathrm{J}_{\mathrm{B}}=$ banyaknya peserta kelompok bawah

$\mathrm{B}_{\mathrm{A}}=$ banyaknya peserta kelompok atas yang menjawab soal itu dengan benar

$\mathrm{B}_{\mathrm{B}}=$ banyaknya peserta kelompok bawah yang menjawab soal itu dengan benar

$\mathrm{P}_{\mathrm{A}}=$ proporsi peserta kelompok atas yang menjawab soal itu dengan benar

$\mathrm{P}_{\mathrm{B}}=$ proporsi peserta kelompok bawah yg menjawab soal itu dengan benar

Klasifikasi daya pembeda :
$0,00-0,20=$ jelek
$0,20-0,40=$ cukup
$0,40-0,70=$ baik
$0,70-1,00=$ baik sekali
(Daryanto, 1997 :190)

\section{c. Analisis Reliabilitas}

Reliabilitas menunjukan bahwa suatu instrumen dapat dipercaya untuk digunakan sebagai pengumpul data, dan apabila digunakan akan memberikan 
hasil yang tetap meskipun diteskan berulang kali.

Untuk menguji reliabilitas soal dihitung dengan menggunakan rumus KR-20 (Khuder Richardson):

$$
r_{11}=\left(\frac{k}{k-1}\right)\left(\frac{S^{2}-\sum p q}{S^{2}}\right)
$$

Keterangan :

$r_{11}=$ reliabilitas instrumen

$\mathrm{k}$ = banyaknya butir pertanyaan

$\mathrm{S}^{2}=$ Variansi soal

$\Sigma p q=$ jumlah hasil perkalian $p$ dan $q$

$\mathrm{p}=$ proporsi subjek yang menjawab item benar

$\mathrm{q}$ = proporsi subjek yang menjawab item salah

$\mathrm{p}=\frac{\text { banyaknya subjek yang skornya } 1}{n}$

Selanjutnya untuk mengetahui instrumen penelitian reliabel atau tidak maka harga $r_{11}$ dari KR-20 dibandingkan dengan $r_{\text {tabel }}$ dengan $\alpha=0.05$ dan derajat kebebasan $\mathrm{dk}=\mathrm{n}-2$. Untuk $\mathrm{r}_{11}$ lebih besar dari $r_{\text {tabel }}$ berarti reliabel, sebaliknya untuk $r_{11}$ lebih kecil dari $r_{\text {tabel }}$ berarti tidak reliabel. Ini digunakan untuk mengetahui apakah instrumen bersifat tetap dalam setiap penelitian. (Surharsimi Arikumto, 2006: 188)

\section{F. Hipotesis Penelitian}

Untuk mengetahui apakah terdapat perbedaan rata-rata hasil belajar fisika siswa antara kelopok siswa yang memakai pengorganisasian materi menggunakan analisis intruksional dengan kelompok siswa yang menggunakan buku paket, maka dapat dirumuskan hipotesis statistiknya yaitu :

$$
\begin{aligned}
& \mathrm{H}_{0}: \mu_{\mathrm{A}}=\mu_{\mathrm{B}} \\
& \mathrm{H}_{1}: \mu_{\mathrm{A}}>\mu_{\mathrm{B}}
\end{aligned}
$$

Keterangan :

$\mu_{\mathrm{A}}=$ Rata-rata hasil belajar siswa yang memakai modul pengorganisasian materi menggunakan analisis intruksional

$\mu_{\mathrm{B}}=$ Rata-rata hasil belajar siswa yang menggunakan pengorganisasian materi menggunakan silabus

$\mathrm{H}_{0}=$ Hipotesis nol, yaitu mean hasil belajar siswa yang memakai pengorganisasian materi menggunakan analisis intruksional sama dengan mean hasil belajar siswa menggunakan pengorganisasian materi menggunakan silabus.

$\mathrm{H}_{1}=$ Hipotesis penelitian, yaitu mean hasil belajar siswa yang memakai pengorganisasian materi menggunakan analisis intruksional lebih tinggi dari pada mean hasil belajar siswa menggunakan pengorganisasian materi menggunakan silabus.

\section{PEMBAHASAN}

\section{A. Deskripsi Data}

\section{Data Sebelum Perlakuan}

a. Analisis Hasil Pre-Test

Pada awal pertemuan kelas eksperimen dan kelas kontrol diberi pre-test untuk mengetahui kemapuan awal siswa. Berikut tabel hasil pre-test kelas eksperimen dan kelas kontrol.

Tabel 4. Analisis hasil pre-test

\begin{tabular}{|l|c|c|c|c|c|}
\hline \multicolumn{1}{|c|}{ Kelas } & Mean & Modus & Median & Varians & Simpangan baku \\
\hline Eksperimen & 29,3 & 28,91 & 28,357 & 170,286 & 13,049 \\
\hline Kontrol & 30,2 & 29 & 29,3 & 110,2348 & 10,4993 \\
\hline
\end{tabular}

Tabel 4 di atas diperoleh dari tebel distribusi frekuensi yang terdapat dalam Iampiran. Untuk menggambarkan tabel distribusi frekuensi, berikut dihadirkan grafik hasil pre-tes untuk masing-masing kelas. 


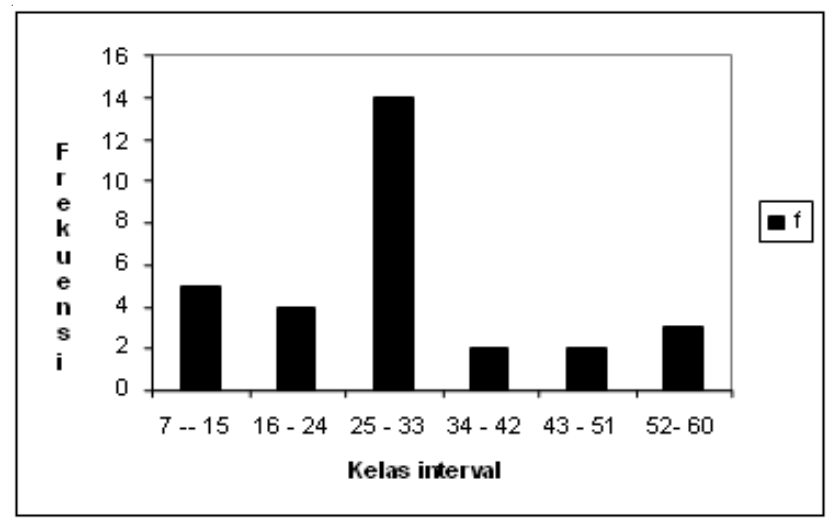

Grafik 1. Analisis hasil pre-test kelas eksperimen

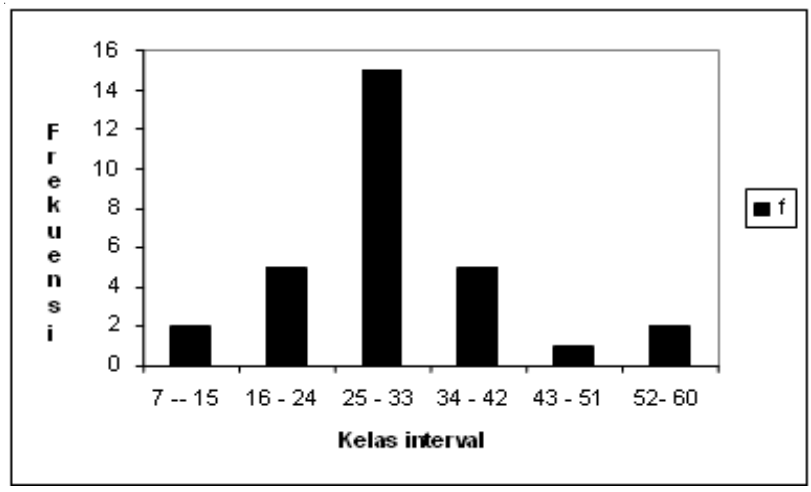

Grafik 2. Analisis hasil pre-test kelas kontrol

Dari tabel dan grafik di atas dapat menggambarkan kemampuaan awal kelas eksperimen dan kelas kontol hapir sama, yaitu memiliki rata-rata nilai yang tidak jauh dan modus nilai yang hapir sama.

Setelah menganalisa hasil pre-test dengan distribusi frekuensi, kemudian untuk mengetahui secara statistik bahwa kelas eksperimen dan kelas kontrol memiliki nilai rata-rata yang sama digunakan uji-t, namun sebelum itu data tersebut akan diuji terlebih dahulu normalitasnya dan homogenitasnya.

b. Uji Normalitas

Untuk menguji normalitas hasil pretest kedua kelas sampel digunakan uji Liliefors, dimana untuk lebih lengkap perhitungan uji Liliefors bisa dilihat di Iampiran. Untuk menggambarkan uji normalitas maka dibuat grafik untuk masing-masing kelas sampel.

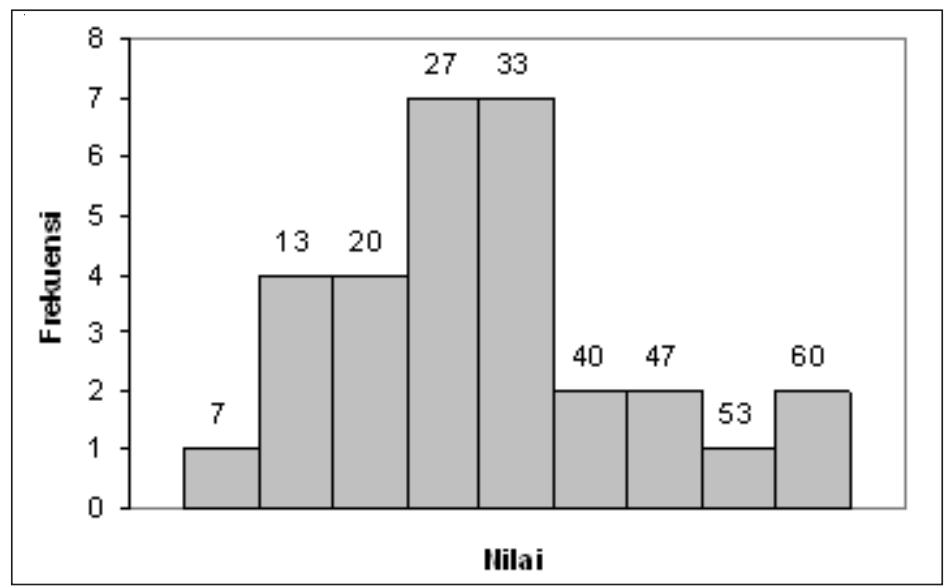

Grafik 3. Uji Normalitas pre-test kelas eksperimen 
Dari hasil perhitungan uji Liliefors untuk kelas eksperimen diperoleh harga $L_{0}=0,1567$, bila dibandingkan harga kritis uji Liliefors untuk $n=30$ dan á $=0.05$, didapat $\mathrm{L}_{\text {tabel }}=0,161$. Karena $\mathrm{L}_{0}(0,1567)<\mathrm{L}_{\text {tabel }}(0,161)$, maka $\mathrm{H}_{0}$ diterima. Oleh karena itu, dapat disimpulkan bahwa data populasi kelas eksperimen sebelum diberikan perlakuan berdistribusi normal.

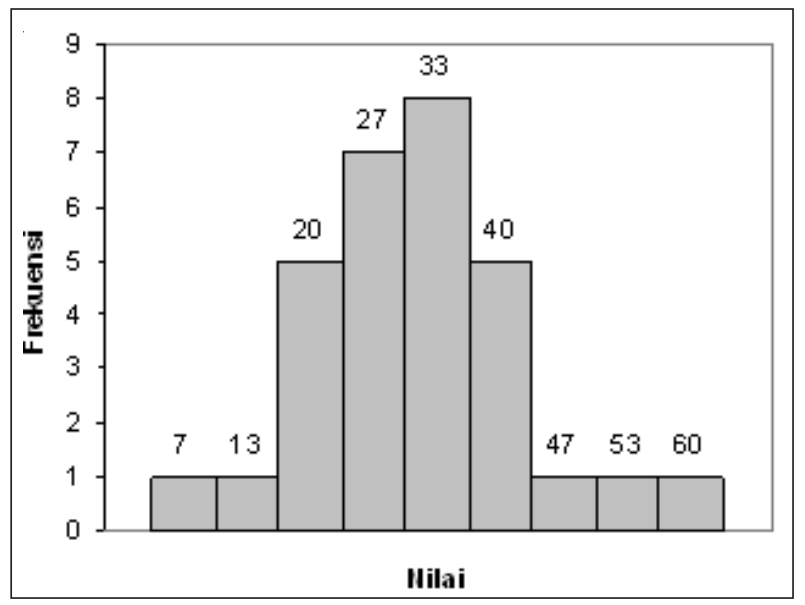

Grafik 4. Uji Normalitas post-test kelas kontrol

Dari hasil perhitungan uji Liliefors untuk kelas kontrol diperoleh harga $\mathrm{L}_{0}=0,1266$, bila dibandingkan harga kritis uji Liliefors untuk $\mathrm{n}=30$ dan á $=$ 0.05 , didapat $\mathrm{L}_{\text {tabel }}=0,161$. Karena $\mathrm{L}_{0}(0,1266)<\mathrm{L}_{\text {tabel }}(0,161)$, maka $\mathrm{H}_{0}$ diterima. Oleh karena itu, dapat disimpulkan bahwa data populasi kelas kontrol sebelum diberikan perlakuan berdistribusi normal.

Karena kedua kelas sampel berdistribusi normal, maka data di atas termasuk parametrik. Oleh karena itu, pengujian dapat dilanjutkan dengan uji homognitas.

c. Uji Homogenitas

Untuk menguji homogenitas kedua sampel digunakan uji Fisher (Uji F). Untuk lebih lengkap perhitungan terlampir, dari hasil perhitungan uji $F$ diperoleh nilai $F_{\text {hitung }}=1,54775$. Kemudian dari daftar distribusi $F$ didapat: $F_{0.975(29,29)}=0,5824$ dan $F_{0.025(29,29)}=2,10$. Karena $F_{\text {hitung }}$ terletak antara $\mathrm{F}_{0.975(29,29)}$ dan $\mathrm{F}_{0.025(29,29)}$ yaitu $0,5824<1,54475<2,10$ sehingga dalam taraf nyata $0.05 \mathrm{H}_{0}$ diterima. Oleh karena itu, dapat disimpulkan bahwa variansi dari kedua kelompok adalah sama. Dengan demikian kedua sampel berasal dari populasi yang homogen. Oleh karena itu, pengujian dapat dilanjutkan ke pengujian hipotesis yaitu dengan menggunakan uji-t.

\section{d. Uji Hipotesis}

Karena kedua populasi homogen atau variansinya sama maka pengujian hipotesis dapat menggunakan uji-t. Untuk perhitungan lebih lengkap terdapat dalam Iampiran. Dari hasil perhitungan diperoleh nilai $t_{\text {hitung }}=$ 0,294 , kemudian dicari nilai $t_{\text {tabel }}$ pada taraf signifikansi 0.05 dan derajat kebebasan 58 adalah 1,6561. Maka didapat $t_{\text {hitung }}(-0,294)<t_{\text {tabel }}(1,6561)$. $\mathrm{Hal}$ ini berarti bahwa $\mathrm{H}_{0}$ diterima dan $\mathrm{H}_{1}$ ditolak. Jadi dapat disimpulkan bahwa rata-rata populasi kelas eksperimen sebelum perlakuan sama dengan kelas kontrol.

Dengan kesimpulan tersebut menegaskan bahwa kelas ekperimen dan kelas kontrol sebelum diberi perlakuan memiliki rata-rata nilainya sama bahkan lebih kecil.

\section{Data Setelah Perlakuan (Hasil Belajar)}

a. Analisis Hasil Post-Test

Setelah kedua kelas sampel diberi perlakuan atau pembelajaran, maka kedua sampel diberi post-test dengan instrumen tes yang sama dengan pretest. Berikut tabel hasil post-test kelas eksperimen dan kelas kontrol.

Tabel 5. Analisis hasil Post-test

\begin{tabular}{|l|c|c|c|c|c|}
\hline \multicolumn{1}{|c|}{ Kelas } & Mean & Modus & Median & Varians & Simpangan baku \\
\hline Eksperimen & 68,3 & 76,83 & 71,5 & 182,51 & 13,509 \\
\hline Kontrol & 55,167 & 58,5 & 65,357 & 151,54 & 12,31 \\
\hline
\end{tabular}


Tabel 5 di atas diperoleh dari tebel distribusi frekuensi yang terdapat dalam lampiran. Untuk menggambarkan tabel distribusi frekuensi, berikut dihadirkan grafik hasil post-tes untuk masing-masing kelas.

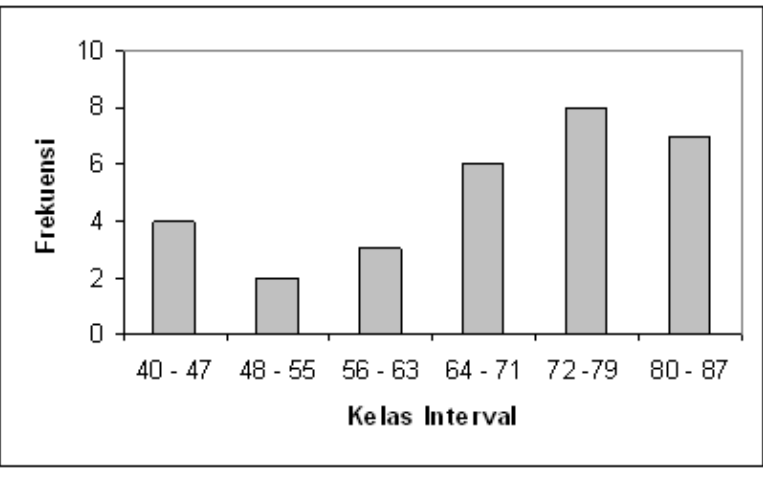

Grafik 5. Analisis hasil post-test kelas eksperimen

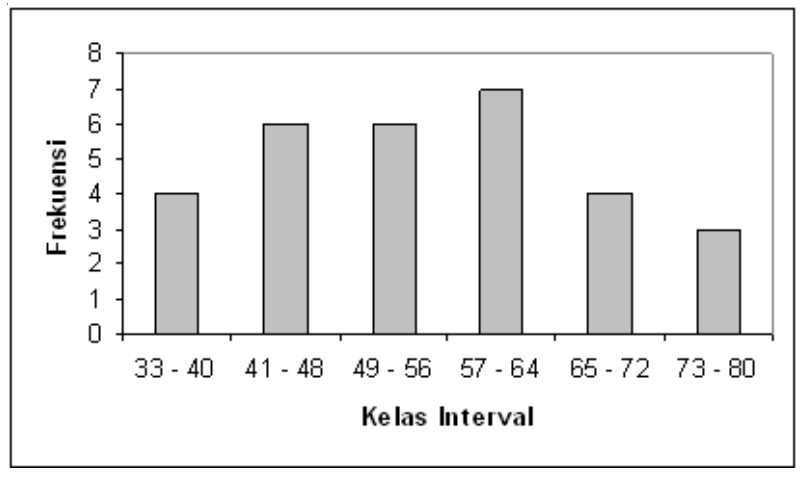

Grafik 6. Analisis hasil post-test kelas kontrol

digunakan uji-t, namun sebelum itu data tersebut akan diuji terlebih dahulu normalitasnya dan homogenitasnya.

\section{b. Uji Normalitas}

Untuk menguji normalitas hasil post-test kedua kelas sampel digunakan uji Liliefors, dimana untuk lebih lengkap perhitungan uji Liliefors bisa dilihat di lampiran. Untuk menggambarkan uji normalitas maka dibuat grafik untuk masing-masing kelas sampel. kelas eksperimen memiliki rata-rata nilai

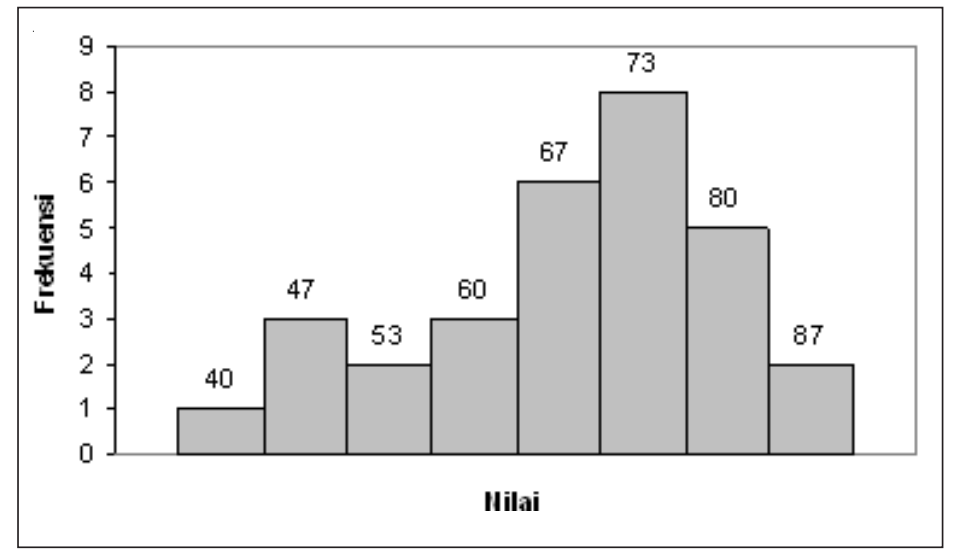

Grafik 7. Uji Normalitas post-test kelas eksperimen

Dari hasil perhitungan uji Liliefors untuk kelas eksperimen diperoleh harga $\mathrm{L}_{0}=$ 0,1292 , bila dibandingkan harga kritis uji Liliefors untuk $\mathrm{n}=30$ dan á $=0.05$, didapat $L_{\text {tabel }}=0,161$. Karena $L_{0}(0,1292)<L_{\text {tabel }}$ $(0,161)$, maka $\mathrm{H}_{0}$ diterima. Oleh karena itu, dapat disimpulkan bahwa data populasi kelas eksperimen setelah diberikan perlakuan berdistribusi normal. 


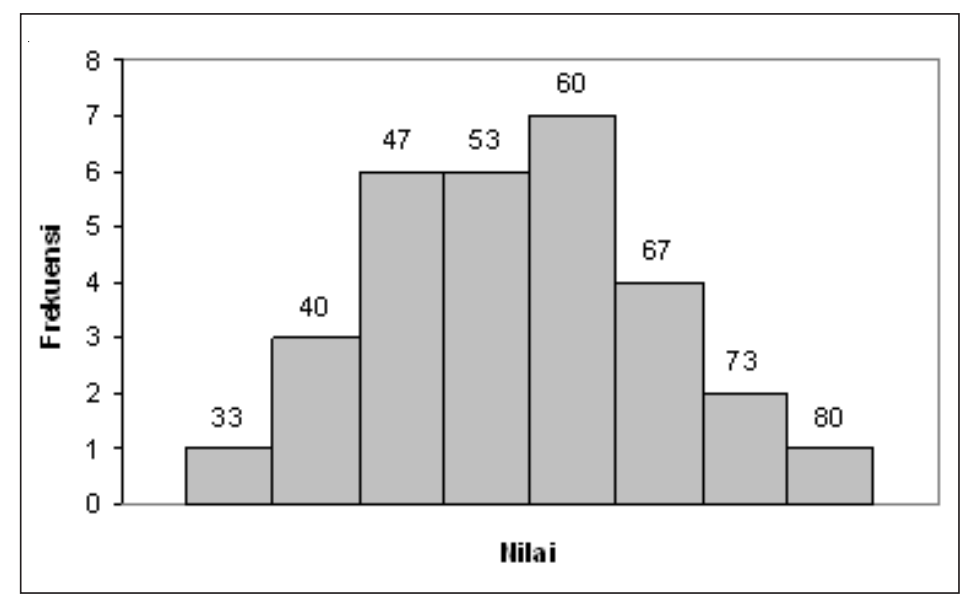

Grafik 8. Uji Normalitas post-test kelas kontrol

Dari hasil perhitungan uji Liliefors untuk kelas kontrol diperoleh harga $L_{0}=0,1143$, bila dibandingkan harga kritis uji Liliefors untuk $\mathrm{n}=30$ dan á $=0.05$, didapat $\mathrm{L}_{\text {tabel }}=$ 0,161 . Karena $L_{0}(0,1143)<L_{\text {tabel }}(0,161)$, maka $\mathrm{H}_{0}$ diterima. Oleh karena itu, dapat disimpulkan bahwa data populasi kelas kontrol setelah diberikan perlakuan berdistribusi normal.

Karena kedua kelas sampel berdistribusi normal, maka data di atas termasuk parametrik. Oleh karena itu, pengujian dapat dilanjutkan dengan uji homognitas.

\section{c. Uji Homogenitas}

Untuk menguji homogenitas kedua sampel digunakan uji Fisher (Uji F). Untuk lebih lengkap perhitungan terlampir, dari hasil perhitungan uji $F$ diperoleh nilai $F_{\text {hitung }}$ $=1,2043$. Kemudian dari daftar distribusi $F$ didapat: $F_{0.975(29,29)}=0,5824$ dan $F_{0.025(29,29)}=2,10$. Karena $F_{\text {hitung }}$ terletak antara $\mathrm{F}_{0.975(29,29)}$ dan $\mathrm{F}_{0.025(29,29)}$ yaitu $0,5824<1,54475<2,10$ sehingga dalam taraf nyata $0.05 \mathrm{H}_{0}$ diterima. Oleh karena itu, dapat disimpulkan bahwa variansi dari kedua kelompok adalah sama. Dengan demikian kedua sampel berasal dari populasi yang homogen, sehingga pengujian dapat dilanjutkan ke pengujian hipotesis yaitu dengan menggunakan ujit.

\section{d. Uji Hipotesis}

Karena kedua populasi homogen atau variansinya sama, maka pengujian hipotesis dapat menggunakan uji-t. Untuk perhitungan lebih lengkap terdapat dalam lampiran. Dari hasil perhitugan diperoleh nilai $t_{\text {hitung }}=2,783$, kemudian dicari nilai $\mathrm{t}_{\text {tabel }}$ pada taraf signifikansi 0.05 dan derajat kebebasan 58 adalah 1,6561. Maka didapat $\left.\mathrm{t}_{\text {hitung }} 2,783\right)>\mathrm{t}_{\text {tabel }}(1,6561)$. Hal ini berarti bahwa $\mathrm{H}_{0}$ ditolak dan $\mathrm{H}_{1}$ diterima. Jadi dapat disimpulkan bahwa rata-rata populasi kelas eksperimen setelah perlakuan lebih besar dari pada kelas kontrol.

Dengan diterimanya $\mathrm{H}_{1}$, maka menyatakan bahwa pengorganisasian materi menggunakan analsis intruksional berpengaruh terhadap hasil belajar siswa.

\section{KESIMPULAN DAN SARAN}

\section{A. Kesimpulan}

Berdasarkan analisis dan perhitungan yang dilakukan terhadap data yang diperoleh dari penelitian, maka dapat disimpulkan bahwa pengorganisasian materi menggunakan analisis instruksional yang diterapkan di kelas eksperimen berpengaruh signifikan terhadap peningkatan hasil belajar siswa. Hal ini sesuai dengan hasil uji hipotesis dimana $\mathrm{H}_{0}$ ditolak, sedangkan $\mathrm{H}_{1}$ diterima untuk hasil belajar siswa. Dengan diterimanya $\mathrm{H}_{1}$, maka dapat disimpulkan bahwa hasil belajar siswa yang diajar dengan pengorganisasian materi menggunakan analisis intruksional lebih tinggi dari pada hasil belajar siswa dengan pengorganisasian materi menggunakan silabus.

Sehubungan dengan itu, maka pengorganisasian materi menggunakan 
analisis intruksional dapat digunakan sebagai salah satu cara untuk meningkatkan hasil belajar siswa. Karena dengan materi yang terorganisir sistematis dengan baik dapat memudahkan siswa memahami materi dan memotivasi siswa untuk terus belajar, sehingga akhirnya tujuan pembelajaran dapat tercapai.

\section{B. Saran}

Dengan adanya pengaruh antara pengorganisasian materi menggunakan analisis intruksional terhadap hasil belajar siswa, maka cara ini dapat digunakan oleh para guru untuk memudahkan penyampaian materi dalam kegiatan belajar mengajar.

Dalam penelitian ini, pengorganisasian materi yang diteliti hanya tentang materi Energi dan Usaha, ada baiknya untuk menyempurnakan metode ini materi yang diteliti bisa menggunakan materi atau kompetensi dasar yang lain. Dan juga, tidak menutup penelitian yang dilakukan hanya pengaruh atau perbedaan, bisa juga metode ini diteliti dengan penelitian tindakan kelas, sehingga menghasilkan pengorganisasian materi yang lebih baik di terapkan di dalam pembelajaran.

\section{DAFTAR PUSTAKA}

Ari H. Gunawan. 1986. Kebijakan-kebijakan pendidikan di Indonesia.Bina Aksara.Jakarta

Daryanto. 2001. Evaluasi Pendidikan. Rineka Cipta. Jakarta

Diana Nomida. 1993. Aspek pengorganisasian dan penyajian materi ajar dalam upaya meningkatkan kesadaran sejarah siswa SMA. Jakarta : Lembaga Penelitian IKIP.

Djajadi Sastara Jusup, 1982. Metoda-metoda Mengajar II. Bandung : Angkasa

Djamarah, Syaiful Bahri dan Aswan Zain. 2002. Strategi Belajar Mengajar. Jakarta: Rineka Cipata.

Hoopkins, David. 1985.A Teacher's Guide To Classroom Research. Philadelphia: University Press.
Horson, William. 2000. Designing Web Based Training, John Wiley \& Son Inc. USA

K. Roestiyah N. (2001). Strategi Belajar Mengajar. Jakarta. Rineka Cipta

M. Abd. Gafur. 1983. Desain Intruksional. Jakarta: APT IKIP.

M. David Merrill. 1994. Instructional Design theory and Models: Overview of their current static. New Jersey: Lawrence Erlbaum Associates.

Muhsin Lubis. 1999. Evaluasi Proses dan Hasil Pembelajaran. Jakarta : FMIPA - UNJ.

Muhyadi. 1989. Organisasi : teori, struktur dan proses. Yogyakarta: FPIPS - IKIP Yogyakarta

Nursyamsudin. 2003. Pedoman Khusus Pengembangan Silabus dan Penilaian. Jakarta: Depdiknas.

Poerwodarminta W. J. S. 1985. Kamus Umum Bahasa Indonesia. Jakarta : Balai Pustaka

Sagala Syaiful. 2003. Konsep dan Makna Pembelajaran. Bandung : Alfabeta

Semiawan, Conny. 1985. Pendekatan Keterampilan Proses : Bagaimana Mengaktifkan Siswa dalam Belajar. Jakarta : PT. Gramedia

Subana, Moersetyo Rahadi dan Sudrajat. 2005. Statistik Pendidikan. Bandung: CV Pustaka Setia.

Sudarmanto YB. 1999. Tuntunan Metode Belajar. Jakarta : Gramedia

Suharsimi Arikunto. 2006. Prosedur Penelitian Suatu Pendekatan Praktik (Edisi Revisi VI). PT. Rineka Cipta. Jakarta

Sujana Nana. 1990. Penilaian Hasil Proses Belajar Mengajar. Bandung : Remaja Rosdakarya

Tarsono. 1997. Pengorganisasian Materi kalor dengan menggunakan CDT. FMIPA : IKIP Jakarta.

Wianaryo Surakhmad. 1984. Pengantar Interksi mengajar belajar. Tarsito: Bandung.

Wiryawan, Sri Anitah dan Noorhadi. 1994. Strategi Belajar Mengajar. Jakarta: Universitas Terbuka 